\title{
Peran Usaha Mikro, Kecil, dan Menengah dalam Mengurangi Tingkat Pengangguran dan Kemiskinan di Kota Palopo
}

\author{
Nirwan*, Baharuddin Semmaila², Aminuddin ${ }^{3}$ \\ ${ }^{1}$ Program Magister Ilmu Ekonomi, Universitas Muslim Indonesia. \\ 2,3 Program Magister Ilmu Manajemen, Universitas Muslim Indonesia.
}

*Email Korespondensi: mynameisnirwan@gmail.com

\begin{abstract}
Abstrak
Penelitian ini bertujuan untuk mengetahui peran UMKM dalam mengurangi tingkat Pengangguran dan Kemiskinan: (1) menguji dan meganalisa peran UMKM dalam mengurangi tingkat pengangguran (2) menguji dan meganalisa peran UMKM dalam mengurangi Kemiskinan. Penelitian ini menggunakan pendekatan kuantitatif adapun metode yang digunakan dalam penelitian ini yaitu regresi linear sederhana dengan menggunakan data Sekunder (Time Series) tahun 2016-2020. Hasil penelitian ini berdasarkan hasil pengolahan data antara variabel UMKM dan Pengangguran dari hasil uji Parsial didapat t-hitung sebesar -2.413, t-tabel sebesar 2.353 sedangkan dari uji korelasi tingkat Signifikansi $(<0.01)$ didapat tingkat segnifikansi sebesar 0.047, dengan demikian bahwa thitung -2,413 > 2,353 t-tabel dan signifikansi $0.047<0.05$ yang artinya terdapat hubungan (-) negative dan signifikan antara UMKM dan tingkat pengangguran. Sedangkan antara variabel UMKM dan Kemiskinan dari hasil uji Parsial didapat t-hitung -6,018 > 2,353 t-tabel dan nilai signifikansi sebesar 0,009<0,05 yang artinya terdapat hubungan () negative dan signifikan antara UMKM dan Kemiskinan. Hal ini berarti artinya jika UMKM mengalami kenaikan tingkat pengangguran mengalami penurunan, begitupun jika UMKM mengalami kenaikan maka kemiskinan mengalami penurunan.
\end{abstract}

Kata Kunci: UMKM, Tingkat Pengangguran, Kemiskinan

\section{Pendahuluan}

Ketika terjadi krisis ekonomi pada tahun 1997 hanya sektor UMKM yang bertahan dari kolapsnya ekonomi, sementara sektor yang lain justru sebagian besar tumbang oleh krisis. Krisis ini telah membuat kedudukan posisi pelaku sektor ekonomi berubah, usaha besar satu persatu pailit karena bahan baku impor meningkat secara drastis, biaya cicilan meningkat sebagai akibat dari nilai tukar Rupiah terhadap Dollar menurun dan berfluktuasi. Sektor perbankan yang terpuruk turut memperparah sektor industri dari sisi permodalan banyak perusahan yang tidak mampu lagi meneruskan usaha karena tingkat bunga yang tinggi, berbeda dengan UMKM yang sebagian besar tetap bertahan bahkan cenderung bertambah. Terbukti beberapa waktu lalu ketika terjadi krisis global, UMKM hadir sebagai suatu solusi dari sistem perekonomian yang sehat, UMKM merupakan sala satu sektor industri yang sedikit bahkan tidak terkena dampak krisis global yang melanda dunia. Dengan bukti ini bahwa jelas UMKM dapat diperhitungkan dalam meningkatkan kekompetitifan pasar dan stabilisasi sistem ekonomi yang ada (Hermanto, 2016).

Usaha mikro, Kecil, dan menengah atau UMKM tergolong jenis usaha marginal, ditandai dengan penggunaan teknologi yang relatif sederhana, tingkat modal dan akses terhadap kredit yang rendah, serta cenderung berorientasi pada pasar lokal. Namun demikian sejumlah kajian di beberapa negara menunjukkan bahwa UMKM berperanan cukup besar bagi pertumbuhan ekonomi, menyerap tenaga kerja melalui penciptaan lapangan pekerjaan, menyediakan barang dan jasa dengan harga murah, serta mengatasi masalah kemiskinan (Maksimov et al., 2017). Di samping itu, UMKM juga merupakan salah satu komponen utama pengembangan ekonomi lokal, di Indonesia, usaha mikro, 
usaha kecil dan menengah telah memberikan kontribusi yang signifikan kepada perekonomian nasional (Nurhilalia et al., 2019). Usaha mikro bersama usaha kecil juga mampu bertahan menghadapi goncangan krisis ekonomi yang melanda Indonesia sejak pertengahan tahun 1997. Indikatornya antara lain, serapan tenaga kerja antara kurun waktu sebelum krisis dan ketika krisis berlangsung tidak banyak berubah, dan pengaruh negatif krisis terhadap pertumbuhan jumlah usaha mikro dan kecil lebih rendah dibanding pengaruhnya pada usaha menengah dan besar. Lebih jauh lagi, usaha mikro dan usaha kecil telah berperan sebagai penyangga (buffer) dan katup pengaman (safety valve) dalam upaya mendorong pertumbuhan ekonomi, serta menyediakan alternatif lapangan pekerjaan bagi para pekerja sektor formal yang terkena dampak krisis (Ahmad et al., 2020; Ilyas et al., 2020; Indahingwati et al., 2019).

UMKM merupakan suatu bentuk usaha masyarakat yang pendiriannya berdasarkan inisiatif seseorang. Sebagian besar masyarakat beranggapan bahwa UMKM hanya menguntungkan pihakpihak tertentu saja. Padahal sebenarnya UMKM sangat berperan dalam mengurangi tingkat pengangguran yang ada di indonesia. UMKM dapat menyerap banyak tenaga kerja yang masih menganggur, selain itu mereka juga memanfaatkan berbagai sumber daya alam yang potensial di suatu daerah yang belum diolah secara komersial (Agustina et al., 2020). UMKM mampu menunjukkan kriteria dan ciri seperti jumlah usaha dan omzet dari kegiatan yang dihasilkan, orientasi, dan manajemen SDM (Haerani et al., 2020). Dengan demikian UMKM juga dapat menjadi salah satu jalan untuk mengurangi tingkat pengangguran yang ada dengan melakukan pelatihan dan sosialisasi terhadap masyarakat mengenai UMKM, sehingga masyarakat dapat menciptakan lapangan pekerjaan sendiri sesuai keinginan dan kemampuan masing-masing individu. Oleh sebab itu UMKM perlu mendapatkan perhatian khusus dari pemerintah sebagai salah satu lapangan pekerjaan bagi masyarakat, sehingga dengan adanya UMKM ini pertumbuhan ekonomi di suatu daerah akan meningkat dan jumlah pengangguran juga akan berkurang. Harapan pada para pengusaha nasional berskala besar sebagai aktor pembangunan yang mampu berkopentensi di pasar global hampir pupus, karena masalah kualitas kemampuan dan moral. Krisis yang lalu menunjukkan bahwa pengusaha enterprenuer sejati sangat langka di bumi pratiwi ini (Arfah et al., 2020). Hampir seluruh pengusaha nasional berskala besar lumpuh karena usahanya bertopang pada fasilitas pemerintah termasuk pembiayaannya. Kebanyakan mereka rapuh karena hanya bermodalkan pertemanan dengan pejabat/ Pengusaha. Dengan mempertimbangkan kondisi tersebut, maka pemberdayaan UMKM menjadi suatu yang niscaya dan perlu dilakukan karena melalui penguatan UMKM di yakini akan dapat di capai pemulihan ekonomi (Ceric, 2017; Švárová \& Vrchota, 2014; Vuong et al., 2020).

Usaha kecil sendiri pada dasarnya sebagaian besar bersifat informal dan karena itu relatif mudah untuk di masuki oleh pelaku-pelaku usaha baru sehingga persoalan pengangguran akan segera dapat di tanggulangi dan bukan tidak mungkin produk-produk UMKM justru menjadi substitusi bagi produk-produk usaha besar yang mengalami kebangkrutan. Meski demikan, ada juga pendapat yang mengatakan sektor informal tidak memberikan perbaikan secara berarti terhadap taraf hidup para pekerjanya. Hidup di sektor informal hanyalah hidup secara subsistem. Kemampuan usaha mikro, kecil dan menengah (UMKM) untuk bertahan dengan sumber daya pribadi inilah mambuat banyak kalangan merasa optimis bahwa usaha mikro, kecil menengah (UMKM) dimasa sekarang dan dimasa depan merupakan tonggak penyelamat ekonomi nasional (Dahliah et al., 2020). Usaha mikro, kecil dan menengah (UMKM) sebagai penyelamat bagi perekonomian karena merekalah yang masih mampu menjadi pemasok kebutuhan masyakat, dan mereka juga masih mampu memberikan lapangan kerjaan. Perusahaan Kecil yang selama ini ternyata terbukti mempunyai daya tahan lebih baik menghadapi terpaan dan guncangan resis ekonomi dunia, perusahaan besar banyak yang tumbang atau paling tidak, wujud kerja mereka tidak seperti yang diharapkan, meskipun dengan mengatakan demikian tidak berarti bahwa peran perusahaan tidak diperlukan. Tidak pernah ada Negara yang perekonomiannya kuat dan kokoh tanpa memiliki perusahaan kecil atau dengan kata lain, sebuah negara perekonomiannya akan kuat dan kokoh apabila ketiga pelaku inti perekonomian, yaitu perusahaan besar, perusahaan menengah, dan perusahaan kecil, dapat tumbuh dan berkembang dengan normal (Aida, 2021). Fakta tentang keberhasilan usaha kecil untuk eksis di tengah suasana dan kondisi perekonomian yang tidak menentu di tentukan oleh banyak faktor, misalnya karena UMKM di kelola oleh orang-orang yang memiliki kompetensi khusus, mereka mengenali titik kelemahan kemudian mengatasinya dengan mencari keterampilan yang di perlukan untuk memastikan sukses dari perusahaan mereka (Lestari et al., 2020; Lorenzo et al., 2018; Sett, 2018). 
Diera globalisasi ini perkembangan UMKM begitu meningkat dari tahun ketahun dari data Badan pusat dan statistik (BPS) UMKM di Indonesia mengalami kenaikan setiap tahunnya, pada tahun 2010 sekitar 52,8 juta unit UMKM dan sedangkan data terakhir BPS tahun 2018 menunjukan peningkatan dimana jumlah unit UMKM naik 64,2 juta. Di Kota Palopo sendiri sebagai Kota yang terletak diantara 3 kabupaten yang ada yaitu Luwu, Luwu Utara, dan Tanah Toraja. Dimana Kota Palopo yang posisinya ditengah diantara kabupaten dan sebagai Kota Penghubung antara Kota karna letaknya yang sangat strategis tersebut membuatnya sebagai magnet bagi para pelaku usaha untuk mengembangkan usahanya, dan UMKM sebagai salah satu pilihan yang tepat. Berdasarkan data dari Dinas Koperasi dan UMKM Kota Palopo jumlah UMKM dari tahun 2016-2019 UMKM yang ada di Kota Palopo mengalami peningkatan terkecuali tahun 2020 yang mengalami sedikit penurunan dampak dari adanya Pendemi covid-19 yang melanda dunia dan menghantam berbagai sektor termasuk UMKM di Kota palopo,berdasarkan gambar diatas rinciannya dimana tahun 2016 terdapat 6.371 unit UMKM, pada tahun 2017 mengalami kenaikan yaitu berjumlah 6.520 unit, di 2018 naik 6.780 unit, begitupun di tahun 2019 jumlah UMKM naik 6.853 unit dan pada tahun 2020 mengalami sedikit penurunan 6.830 unit. Peningkatan UMKM Kota Palopo menandakan geliat ekonomi di Kota ini kearah yang positif.

Dalam upaya mengurangi tingkat kemiskinan dan Pengangguran pemerintah telah melakukan berbagai upaya. Salah satu keseriusan pemerintah ditunjukkan dengan adanya berbagai macam program pemberdayaan melalui Usaha Mikro Kecil Menengah (UMKM) yaitu usaha yang sinergi antara pemerintah dengan pihak-pihak lain sangat dibutuhkan untuk efektivitas program pemberdayaan (Humam, 2012). Peran UMKM terutama sejak krisis moneter tahun 1997 dapat dipandang sebagai media penyelamat dalam proses pemulihan ekonomi nasional. Selain sebagai salah satu alternative penyediaan lapangan kerja baru, UMKM berperan baik dalam mendorong laju pertumbuhan ekonomi dan sebagai program pengentasan kemiskinan maupun penyerapan tenaga kerja. Berdasarkan uraian yang telah di kemukakan pada latar belakang masalah di atas maka permasalahan yang akan dikaji dalam penelitian ini berkaitan dengan Peran usaha mikro, kecil, dan menengah (UMKM) dalam mengurangi tingkat penggangguran dan kemiskinan Kota Palopo. Dengan bgitu penulis menguraikan fokus batasan Masalah yang akan di teliti yaitu:

1. Apakah Usaha Mikro, kecil, dan Menengah (UMKM) berperan dalam menurunkan tingkat Pengangguran di Kota Palopo?

2. Apakah Usaha Mikro, kecil, dan Menengah (UMKM) berperan dalam Menurunkan kemiskinan di Kota Palopo?

\section{Tinjauan Pustaka}

\section{A. Pengangguran dan Usaha mikro, kecil dan menengah UMKM}

Muslim (2014) dan Mustika (2012) mengungkapkan bahwa Pengangguran merupakan suatu keadaan di mana seseorang yang tergolong dalam angkatan kerja ingin mendapatkan pekerjaan tetapi belum dapat memperolehnya. Seseorang yang tidak bekerja, tetapi tidak secara aktif mencari pekerjaan tidak tergolong sebagai penganggur. Pengangguran dapat terjadi disebabkan oleh tidakseimbangan pada pasar tenaga kerja. Hal ini menunjukkan jumlah tenaga kerja yang ditawarkan melebihi jumlah tenaga kerja yang diminta.Usaha mikro, kecil, dan menengah UMKM tidak saja menjadi tulang punggung dalam menggerakkan roda ekonomi di Indonesia, UMKM juga memainkan peranan penting dalam penciptaan peluang kerja di seluruh Indonesia sejalan dengan yang Kementerian Koperasi dan UKM RI yang mencatat pada Desember 2018, kontribusi 60 juta unit UMKM terhadap Produk Domestik Bruto (PDB) adalah sebesar 60,34 persen dan mampu membantu penyerapan tenaga kerja hingga 97 persen dari total tenaga kerja nasional (BAPPENAS, 2016).

Permasalahan pengangguran juga sangat berperan mempengaruhi angka kemiskinan di Indonesia. Menurut Sukirno (2004) mengemukakan bahwa pengangguran akan menimbulkan efek mengurangi pendapatan masyarakat dan itu akan mengurangi tingkat kemakmuran yang telah dicapai. Dimana, semakin turunnya tingkat kemakmuran akan menimbulkan masalah yaitu kemiskinan. Di dalam studinya JS Saragih (2017) menjelaskan bahwa Angkatan kerja yang tumbuh cepat akan menambah beban tersendiri bagi perekonomian yakni penciptaan atau perluasan lapangan kerja. Jika lowongan kerja baru tidak mampu menampung semua angkatan kerja maka bagian angkatan kerja itu akan memperpanjang barisan pengangguran yang sudah ada. Khurshid \& Snell (2021) mengatakan 
bahwa dalam berbagai sektor ekonomi perlu adanya penguatan UMKM dengan cara memberikan peluang usaha bagi UMKM itu sendiri dan pertimbangan keberadaan UMKM agar mampu membangun struktur ekonomi di Indonesia." Dengan harapan adanya UMKM membantu untuk mengatasi masalah ketenagakerjaan dan dapat menambah pendapatan masyarakat, dengan adanya hal tersebut UMKM juga dapat menjadi salah satu solusi jalan untuk mengurangi tingkat pengangguran yang ada dengan melakukan pelatihan dan sosialisasi terhadap masyarakat mengenai UMKM, sehingga masyarakat dapat menciptakan lapangan pekerjaan sendiri sesuai keinginan dan kemampuan masing-masing individu. Oleh sebab itu UMKM perlu mendapatkan perhatian khusus dari pemerintah sebagai salah satu lapangan pekerjaan bagi masyarakat, sehingga dengan adanya UMKM ini pertumbuhan ekonomi di suatu daerah akan meningkat dan jumlah pengangguran juga akan berkurang,

Lebih lanjut Menurut Hayati \& Rukhviyanti (2016) dan Laurens \& Putra (2020) pengembangan ekonomi rakyat harus diprioritaskan melalui keberpihakkan kepada sektor usaha mikro kecil dan menegah. Sektor UMKM ini memegang peranan yang sentral dan strategis dalam pengembangan ekonomi kerakyatan. Sektor UMKM akan mampu menyerap tenaga kerja yang cukup besar dan bisa diharapkan menjadi penyangga dalam bangkitnya sektor riil. Menurut Anorangga (1997) UMKM merupakan usaha yang memiliki peran yang cukup tinggi terutama di Indonesia yang masih tergolong negara berkembang. Banyaknya jumlah UMKM maka akan semakin banyak penciptaan kesempatan kerja bagi para penganguran. Selain itu UMKM dapat dijadikan sebagai sumber pendapatan khususnya didaerah pedesaan dan rumah tangga berpendapatan rendah.

\section{B. Kemiskinan dan usaha mikro kecil dan menengah UMKM}

Islam et al (2020) dan Kamakura \& Mazzon (2015) menyatakan bahwa kemiskinan merupakan kondisi yang serba terbatas yang terjadi bukan atas kehendak orang yang bersangkutan, lebih lanjut masyarakat dikatakan miskin jika ditunjukkan oleh rendahnya tingkat pendidikan, produktivitas kerja, pendapatan, kesehatan dan gizi serta kesejahteraan hidupnya, yang menunjukkan lingkaran ketidakberdayaan. Birčiaková et al (2014) dan Jenkins (2009) penyebab kemiskinan akan bermuara pada teori lingkaran setan kemiskinan (vicious cycle of proverty). Adanya keterbelakangan, ketidaksempurnaan pasar dan kurangnya modal menyebabkan rendahnya pendapatan yang mereka terima. Rendahnya pendapatan akan mengakibatkan rendahnya pula tabungan. Rendahnya tabungan maka rendah pula investasinya yang bermuara ketidak mampuan dalam memenuhi hidupnya. Halvarsson et al (2018) mengatakan terdapat lima karakteristik penduduk miskin yaitu: Tidak memiliki faktor produksi sendiri, tidak mempunyai kemungkinan untuk memperoleh aset produksi dengan kekuatan sendiri, tingkat pendidikan pada umumnya rendah, banyak di antara mereka yang tidak mempunyai fasilitas, dan Di antara mereka berusia relatif muda, serta tidak mempunyai keterampilan atau pendidikan yang memadai.

Keterkaitan antara dua variabel UMKM dan kemiskinan, tersebut karna Pemberdayaan dan pengembangan UMKM merupakan salah satu cara untuk menanggulangi kemiskinan yang terjadi (Maksimov et al., 2017). Caranya adalah memberikan akses kepada penduduk miskin untuk dapat terlibat dalam berusaha dan aktif dalam kegiatan usaha yang produktif dan memasyarakatkan kewirausahaan terutama di kalangan keluarga miskin atau daerah tertinggal. Menurut Tahir et al (2015); Tohmo (2018) keberadaan UMKM terutama di pedesaan juga mampu membuat orang miskin yang sebenarnya tidak atau belum produktif untuk memperoleh kesejahtraan melalui penghasilan yang didapat baik sebagai pekerja maupun sebagai pemilik, dari kenyataan tersebut dapat disimpulkan keberadaan UMKM tidak hanya mampu menyerap peluang kerja Bagi si miskin yang produktif dan mau berusaha juga dapat menyerap yang tidak atau belum produktif, implikasi langsung dengan terjadinya penterapan tenaga kerja adalah adanya pendapatan yang di terimah sehingga pendapatan tersebut dapat dibelanjakan untuk memenuhi kebutuhan hidup (Simanjuntak \& Putra, 2021).

Indonesia sendiri Pengembangan Usaha Mikro, kecil, dan menengah merupakan salah satu prioritas dalam pembangunan ekonomi nasional. Hal ini selain karena usaha tersebut merupakan tulang punggung sistem ekonomi kerakyatan yang tidak hanya ditujukan untuk mengurangi masalah kesenjangan antar golongan pendapatan dan antar pelaku usaha, ataupun pengentasan kemiskinan dan penyerapan tenaga kerja (Haming et al., 2019; Aditya Halim Putra et al., 2018; Ramlawati et al., 2019). Lebih dari itu, pengembangannya mampu memperluas basis ekonomi dan dapat memberikan konstribusi yang signifikan dalam mempercepat perubahan struktural, yaitu meningkatnya 
perekonomian daerah dan ketahanan ekonomi nasional (Asmin et al., 2021); (Gaffar \& Akkal, 2021); (Alam, Aida, Mukhtar, 2021).

\section{Faktor-faktor yang mempengaruhi pengangguran dan kemiskinan}

Jumlah penduduk merupakan salah satu faktor yang berpengaruh dalam proses pembangunan suatu negara ataupun daerah. Pertumbuhan jumlah penduduk yang semakin meningkat mengakibatkan jumlah angkatan kerja juga mengalami peningkatan, itu artinya pertambahan jumlah penduduk ini akan menjadi maslah jika tidak dibarengi dengan peningkatan lapangan pekerjaan yang mampu menmpekerjakan angkatan kerja tersebut (Ghoshray et al., 2016; Wang et al., 2019), Lebih lanjut dikatakan bahwa Pertumbuhan penduduk yang semakin meningkat telah mengakibatkan jumlah angkatan kerja juga mengalami peningkatan, Itu artinya akan semakin besar pula jumlah orang-orang yang mencari pekerjaan atau menganggur. Agar pertambahan jumlah penduduk tidak menjadi masalah maka pertumbuhan dan kemajuan ekonomi suatu negara deperlukan dalam mengatasi masalah pengangguran (Strat et al., 2015). Pengangguran merupakan masalah yang dihadapi setiap negara di dunia baik negara maju maupun negara berkembang seperti di Indonesia Pada saat ini fakta menunjukkan bahwa yang menjadi kunci dalam pembangunan yaitu penduduk yang memiliki keterampilan dan pendidikan yang mendukung. Terbatasnya lapangan pekerjaan merupakan salah satu faktor yang menyebabkan jumlah pengangguran semakin meningkat. Peningkatan pengangguran yang terus bertambah dikarenakan adanya peningkatan tenaga kerja yang tidak dibarengi dengan peningkatan lapangan pekerjaan sehingga para tenaga kerja bersaing untuk mendapatkan pekerjaan agar tidak menjadi pengangguran (Olilingo \& Putra, 2020). Upah merupakan suatu imbalan yang di dapat dari hasil bekerja pekerjaan atau jasa yang telah dikerjakan. Apabila tingkat uapah semakin tinggi, semakin kecil pula permintaan pengusaha akan tenaga kerja. Kenaikan tingkat upah akan diikuti oleh turunnya jumlah tenaga kerja yang diminta, yang berarti akan menyebabkan bertambahnya jumlah pengangguran (Akob et al., 2020; Mappamiring et al., 2020; Tangngisalu et al., 2020). Upah minimum adalah suatu standar minimum yang digunakan oleh para pengusaha atau pelaku industri untuk memberikan upah kepada pekerja di lingkungan usaha atau kerjanya. Menurut Peraturan Pemerintah No. 78 Tahun 2015 tentang Pengupahan, Pasal 41 ayat 2, "upah minimum merupakan upah bulanan terendah yang terdiri atas: a. upah tanpa tunjangan; atau b. upah pokok termasuk tunjangan tetap". Peraturan Pemerintah ini juga menegaskan bahwa upah minimum hanya berlaku bagi pekerja/buruh dengan masa kerja kurang dari 1 (satu) tahun pada perusahaan yang bersangkutan. Sementara itu, upah bagi pekerja/buruh dengan masa kerja 1 (satu) tahun atau lebih dirundingkan secara bipartit antara pekerja dengan pengusaha di perusahaan yang bersangkutan. Menurut Masripatin (2007) mengatakan penyebab kemiskinan antara lain sebagai berikut: (1) Secara makro, kemiskinan muncul karena adanya ketidaksamaan pola kepemilikan sumber daya yang menimbulkan distribusi pendapatan timpang, penduduk miskin hanya memiliki sumber daya dalam jumlah yang terbatas dan kualitasnya rendah. Lebih lanjut Islam et al (2020) mengutarakan bahwa penyebab kemiskinan dan keterbelakangan adalah persoalan aksesibilitas. Akibat keterbatasan dan ketertiadaan akses manusia mempunyai keterbatasan (bahkan tidak ada) pilihan untuk mengembangkan hidupnya, kecuali menjalankan dengan terpaksa apa yang saat ini dapat dilakukan (bukan apa yang seharusnya dilakukan). Dengan demikian manusia mempunyai keterbatasan dalam melakukan pilihan, akibatnya potensi manusia untuk mengembangkan hidupnya menjadi terhambat. (2) Kemiskinan muncul akibat perbedaan kualitas sumber daya manusia karena kualitas sumber daya manusia yang rendah berarti produktivitas juga rendah, upahnya pun rendah. (3) Kemiskinan muncul sebab perbedaan akses dan modal. (4) Tingkat Pendidikan, Keshvari (2012) mengartikan pendidikan adalah suatu proses pembentukan kecakapan fundamental, baik secara intelektual maupun emosional, kearah alam dan sesama manusia. Dalam upaya mencapai pembangunan ekonomi yang berkelanjutan, pendidikan memiliki peranan sangat strategis dalam mendukung proses produksi dan aktivitas ekonomi lainnya. Dalam konteks ini, pendidikan dianggap sebagai suatu alat untuk mencapai target yang berkelanjutan, karena dengan pendidikan, aktivitas pembangunan dapat tercapai sehingga peluang untuk meningkatkan kualitas hidup di masa mendatang akan lebih baik (Rombe, 2021). 


\section{Penelitian terdahulu}

(1) Penelitian yang dilakukan oleh: Adnan Husada Putra (2016) dengan Judul: Peran UMKM dalam Pembangunan dan Kesejahteraan Masyarakat Kabupaten Blora, dengan hasil Penelitiannya mengatakan bahwa UMKM mampu menumbuhkan pembangunan dan kesejahteraan masyarakat di Kabupaten Blora. (2) Penelitian yang dilakukan oleh: Andiny \& Nurjannah (2018) dengan Judul: Analisis Pemberdayaan Usaha Mikro, Kecil, dan Menengah (UMKM) sebagai upaya Penanggulangan Kemiskinan di Kota Langsa hasil penelitian ini menunjukkan bahwa Pemberdayaan Usaha Mikro, Kecil, dan Menengah (UMKM) berpengaruh terhadap penanggulangan kemiskinan di Kota Langsa. (3) Penelitian yang dilakukan oleh: Rachmawati (2020) dengan Judul: kontribusi sektor UMKM pada upaya pengentasan kemiskinan di indonesia Hasil penelitian ini menunjukkan bahwa Tumbuhnya UMKM sebagai sumber kesempatan kerja dan meningkatkan pendapatan dan banyak menyerap tenaga kerja, dengan demikian UMKM memiliki peran strategis dalam mengentaskan kemiskinan. (4) Penelitian yang dilakukan oleh: Wibawa \& Anggitaria (2020) dengan Judul: Kontribusi Usha Mikro Kecil dan Menengah (UMKM) dalam mengurangi tingkat pengangguran (Studi kasus pada UMKM kerajinan sepatu kulit di Kabupaten Magetan) penelitian ini menunjukkan bahwa UMKM berkontribusi dalam meningkatkan potensi daerah yang dimiliki serta sebagai salah satu solusi untuk mengurangi tingkat penganggutan yang ada di Kabupaten Magetan.

\section{E. Kerangka konseptual}

Adanyanya kecenderungan semakin meningkatnya jumlah UMKM maka tingkat kemiskinan dan pengangguranpun ikut mengalami penurunan inipun dikuatkn dengan teori-teori yang telah disebutkan diatas, berdasarkan kecenderungan dan teori yang ada tersebut maka Kerangka Konsep dalam penelitian ini dimana tingkat pengangguran dan kemiskinan yang ada di Kota Palopo di pengaruhi oleh beberapa faktor diantaranya Jumlah Usaha Mikro, Kecil, dan Menengah (UMKM).

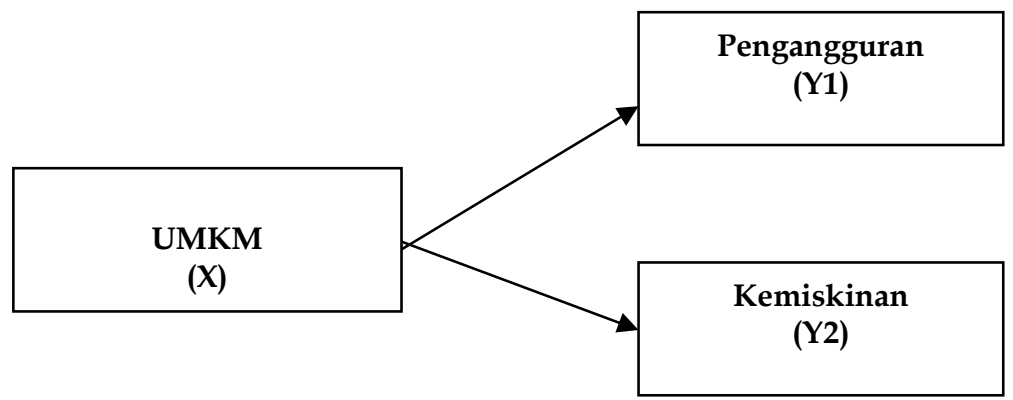

Gambar 1. Kerangka Konseptual

Berdasarkan uraian dan hasil penelitian peneliti terdahulu diatas adapun hipotesis yang dikemukakan peneliti adalah

1. Diduga Usaha mikro, kecil, dan menengah (UMKM) dapat berperan dalam mengurangi tingkat pengangguran.

2. Diduga Usaha mikro, kecil, dan menengah (UMKM) dapat berperan dalam mengurangi kemiskinan.

\section{Metode Penelitian}

Penelitian ini merupakan pendekatan kuantitatif, karena penelitian ini disajikan dengan angkaangka. Menurut (Ghozali, 2011) penelitian kuantitatif adalah pendekatan penelitian yang banyak dituntut menggunakan angka, mulai dari pengumpulan data, penafsiran terhadap data tersebut, serta penampilan hasilnya. Penelitian ini dilakukan di kota Palopo. Tempat penelitian ini dipilih selain karena tempat domisili peneliti juga karena begitu pesatnya perkembangan usaha Mikro, Kecil, dan Menengah (UMKM) terkhusus 5 tahun terakhir di Palopo apakah berbanding terbalik terhadap penurunan jumlah tingkat pengangguran dan kemiskinan. Data yang dipergunakan untuk mendukung penelitian ini adalah data sekunder (Time Series) Tahun 2016-2020, menurut (Sugiyono, 2014) data 
sekunder adalah sumber data yang tidak langsung memberikan data kepada pengumpul data, misalnya lewat orang lain atau lewat dokumen. datanya berasal dari Badan Pusat Statistik Kota Palopo.

Menurut (Sugiyono, 2014) unit analisis adalah satuan tertentu yang diperhitungkan sebagai subjek penelitian. Sedangkan dalam Penelitian ini menggunakan data UMKM, Tingkat Pengangguran, dan Kemiskinan yang ada di Kota Palopo rentan waktu 2016-2020 sebagai unit analisis. Teknik pengumpulan data yang digunakan adalah (1) Observasi adalah alat pengumpulan data yang dilakukan dengan cara mengamati dan mendengar dalam rangka memahami, mencari jawaban, mencari bukti terhadap fenomena yang ada diobsevasi dengan mencatat, merekam, memotret fenomena tersebut guna penemuan data analisis. (2) Dokumentasi adalah suatu cara untuk memperoleh informasi dalam bentuk buku, arsip, laporan dan keterangan yang terkait dengan penelitian ini. (3) Kepustakaan yaitu dengan membaca buku, majalah, surat kabar, dokumen dokumen, undang-undang dan media informasi lain yang ada hubungannya dengan masalah yang diteliti.

Menurut (Sugiyono, 2014) Populasi adalah keseluruhan subjek penelitian, Sedangkan sampel adalah sebagian dari subjek yang diteliti, yang sudah tentu mampu secara representativ dapat mewakili populasinya. Populasi dalam penelitian ini adalah data Perkembangan Usaha Mikro, Kecil dan Menengah (UMKM), tingkat Pengangguran dan Penduduk miskin di Kota Palopo, sedangkan sampel dalam Penelitian ini yaitu UMKM, tingkat Pengangguran dan Penduduk miskin di Kota Palopo pada tahun 2016-2020. Peneliti juga menggunakan teknik sampling jenuh yang menggunakan semua anggota populasi alasannya karena data yang di olah berbentuk sensus yang sudah berbentuk laporan tahunan yang di keluarkan lembaga terkait. Metode analisis Datanya yaitu Analisis regresi Sederhana dimana berfungsi menguji sejauh mana hubungan antara variabel independen $(X)$ dengan variable Dependen $(\mathrm{Y})$. Analisis ini untuk mengetahui arah hubungan antara variabel bebas $(\mathrm{X})$ dengan variabel terikat $(\mathrm{Y}$. Y2).

$\begin{array}{ll} & \mathrm{Y} 1=\alpha+\beta 1 \mathrm{X}+\mathrm{e} \\ \mathrm{Y} 2=\alpha+\beta 1 \mathrm{X}+\mathrm{e}\end{array}$

\section{Pembahasan}

\section{a) Gambaran Singkat Objek Penelitian}

Luas wilayah Kota Palopo tercatat 247,52 km persegi yang meliputi 9 kecamatan dan 48 kelurahan. Kecamatan terluas di Kota Palopo adalah Kecamatan Wara Barat dengan luas 54,13 km persegi atau mencakup 21,87 persen dari luas Kota Palopo secara keseluruhan. Sedangkan, kecamatan dengan luas terkecil adalah Kecamatan Wara Utara dengan luas 10,58 km persegi atau hanya sebesar 4,27 persen dari luas Kota Palopo. Jarak antara Kota Palopo ke Ibukota Provinsi Sulawesi Selatan, Kota Makassar, adalah 390 km (BPS Kota Palopo, 2021:1). Penduduk Kota Palopo tahun 2020 tercatat sebanyak 184.681 jiwa, terdiri dari 92.444 jiwa laki-laki dan 92.237 jiwa perempuan, dengan demikian maka rasio Jenis Kelamin sebesar 100,22, angka ini menunjukkan bahwa bahwa pada 100 penduduk perempuan ada 100-101 penduduk laki-laki. Pertumbuhan penduduk dari tahun 2010 ke 2020 sebesar 2,17 persen. Dengan luas wilayah 247,52 Km maka kepadatan penduduk di Kota Palopo yaitu 746 jiwa per Kilometer persegi. Kecamatan dengan kepadatan penduduk tertinggi yaitu Kecamatan Wara Timur dengan 3.174 jiwa per kilometer persegi. Sedangkan kecamatan dengan kepadatan penduduk terendah adalah kecamatan Mungkajang yaitu 187 per kilometer persegi. Penduduk Usia Kerja (PUK) didefinisikan sebagai penduduk yang berumur 15 tahun keatas. PUK terdiri dari angkatan kerja dan bukan angkatan kerja. Tingkat Partisipasi Angkatan Kerja (TPAK) Kota Palopo adalah sebesar 61,23 persen, sementara Tingkat Pengangguran Terbuka (TPT) nya adalah sebesar 10,37 persen. Sebanyak 
27,18 persen PUK bekerja berpendidikan S1 ke atas. Jika dilihat menurut jam kerja seluruhnya, 68,85 persen PUK bekerja selama 35 jam atau lebih, sedangkan menurut status pekerjaannya, 52,97 persen diantaranya bekerja sebagai buruh/ karyawan/pegawai (BPS Kota Palopo, 2021:86)

Hasil dari SUSENAS Maret 2021 menunjukkan garis kemiskinan Kota Palopo berada pada angka Rp 362.859 dengan persentase penduduk miskin sebesar 7,85 persen. Indeks Pembangunan Manusia (IPM) Kota Palopo tahun 2021 sebesar 78,06 dengan pertumbuhan 0,10 persen. Kota Palopo menempati ranking kedua se- Sulawesi Selatan, berikut Jumlah kemiskinan Kota Palopo dalam rentan waktu 5 tahun terakhir.

Sepanjang 5 tahun terakhir, persentase penduduk miskin menunjukkan tren fluktuasi, Persentase penduduk miskin Maret 2016-Maret 2017 menunjukkan kenaikan 0,04 persen. Selanjutnya periode Maret 2017- Maret 2019 persentase penduduk miskin turun hingga 7,82 persen. Kemudian tren meningkat kembali ditunjukkan pada Maret 2020, persentase penduduk miskin tercatat sebanyak 14,71 . Peningkatan angka kemiskinan pada Tahun 2020 ini diduga disebabkan oleh Pandemik Covid19 yang terjadi sepanjang Tahun 2020 bahkan hingga saat ini. Fenomena ini pun sejalan dengan peningkatan jumlah pengangguran pada Tahun 2020 menjadi 10,37 persen dari 9,67 persen. Penerapan Pembatasan Sosial Berskala Besar (PSBB) memaksa semua lini kegiatan masyarakat dilaksanakan di rumah, mulai dari sekolah, ibadah hingga bekerja untuk memperoleh penghasilan. Dikarenakan terbatasnya ruang gerak memaksa sektor usaha dan jasa mengurangi kegiatan produksi untuk mengurangi kerugian semakin besar, hingga pada akhirnya tidak sedikit pekerja yang dirumahkan bahkan diberhentikan dari pekerjaannya dan memicu peningkatan jumlah penduduk miskin di Tahun 2020. (BPS Kota Palopo, 2021)

Tabel 1. Penduduk Miskin, Pengangguran, dan Jumlah Penduduk Rentan Waktu 2016-2020

\begin{tabular}{|c|c|c|c|}
\hline Tahun & $\begin{array}{c}\text { Jumlah } \\
\text { penduduk miskin (\%) }\end{array}$ & $\begin{array}{c}\text { Jumlah pengangguran } \\
\text { terbuka (\%) }\end{array}$ & $\begin{array}{c}\text { Jumlah Penduduk } \\
\text { (Jiwa) }\end{array}$ \\
\hline 2016 & 8,74 & 14,54 & 176.910 \\
\hline 2017 & 8,78 & 10,96 & 172.920 \\
\hline 2018 & 7.94 & 11,60 & 180.680 \\
\hline 2019 & 7,82 & 10,32 & 184.600 \\
\hline 2020 & 7,85 & 10,37 & 184.681 \\
\hline
\end{tabular}

Sumber, BPS Kota Palopo 2021

Berdasarkan tabel diatas dapat dilihat penduduk miskin di Kota Palopo pada tahun 2016 8,74\% dan jumlah pengangguran terbuka $14,54 \%$ dari 176.910 jiwa penduduk kota palopo, kemudian tahun 2017 penduduk miskin naik $0,04 \%$ jadi 8,78\% dan jumlah pengangguran terbuka mengalami penurunan 3,58\% menjadi 10,96\% sedangkan jumlah penduduknya juga mengalami penurunan 172.920 jiwa, di tahun 2018 penduduk miskin mengalami penurunan 0,84\% menjadi 7.94\%, lalu jumlah pengangguran terbuka mengalami kenaikan 0,64\% menjadi 11,60 dan jumlah penduduk juga naik jadi 180.680 jiwa, tahun 2019 penduduk miskin 7,82\% turun 0,12\% dari jumlah penduduk miskin tahun 2018, sedangkan jumlah pengangguran terbuka 10,32\% turun 1,28\% dari tahun 2018. Dan jumlah penduduk kota Palopo naik 184.600 jiwa, ditahun 2020 presentae penduduk miskin mengalami kenaikan 0,03\% jadi $7.85 \%$, dan jumlah pengangguran terbuka juga mengalami kenaikan 0,05 menjadi $10.37 \%$ ditahun 2020, disaat yang sama jumlah penduduk Kota Palopo sedikit mengalami kenaikan jadi 184.681 jiwa.

\section{b) Deskripsi Hasil Penelitian.}

1. Usaha Mikro,Kecil,dan Menengah UMKM (X) dan Pengangguran (Y1)

a. Uji normalitas

Uji normalitas digunakan untuk mengetahui apakah data yang diperoleh berdistribusi normal atau tidak.Ada dua cara untuk mendeteksi apakah residual berdistribusi normal atau tidak dalam uji normalitas, yaitu dengan cara analisis grafik dan analisis statistik. Uji normalitas ini akan menggunakan uji Kolmogorov-Smirnov. Dasar pengambilan keputusan dalam uji normalitas Kolmogorov smirnov, jika nilai signifikansi $>0,05$ maka nilai residual berdistribusi normal dan jika nilai signifikansi $<0,05$ maka nilai residual tidak berdistribusi normal. 
Tabel 2. Uji Normalitas

\begin{tabular}{|l|l|r|}
\hline \multicolumn{2}{|c|}{ One-Sample Kolmogorov-Smirnov Test } \\
\hline \multicolumn{2}{|c|}{ Unstandardized Residual } \\
\hline N & Mean & 5 \\
\cline { 2 - 3 } & Std. Deviation & .0000000 \\
\hline \multirow{2}{*}{ Most Extreme Differences } & Absolute & 1.01819323 \\
\cline { 2 - 3 } & Positive & .248 \\
\cline { 2 - 3 } & Negative & .164 \\
\hline Test Statistic & -.248 \\
\hline Asymp. Sig. (2-tailed) & .248 \\
\hline a. Test distribution is Normal. & .200 c, \\
\hline b. Calculated from data. & \\
\hline c. Lilliefors Significance Correction. & \\
\hline d. This is a lower bound of the true significance. & \\
\hline
\end{tabular}

Berdasarkan uji normalitas di ketahui nilai signifikansi sebesar 0,200 lebih besar dari 0,05 sehingga dapat disimpulkan data yang dilakukan pengujian terdistribusi secara normal.

b. Uji Analisis Regresi Linear Sederhana

Penelitian ini menggunakan uji analisis regresi linear sederhana untuk memprediksi hubungan antara Usah Mikro, Kecil, dan Menengah (UMKM) dan tingkat pengangguran. Analisis ini menggunakan data Sekunder (Time Series) rentan waktu 5 tahun 2016-2020. Perhitungan uji ini dilakukan dengan bantuan SPSS 22. Adapun hasil dari uji analisis regresi linear sederhana dapat dilihat pada tabel berikut.

Tabel 3. Uji Analisis Regresi

\begin{tabular}{|c|c|c|c|c|c|c|}
\hline \multicolumn{7}{|c|}{ Coefficients ${ }^{a}$} \\
\hline \multirow{2}{*}{\multicolumn{2}{|c|}{ Model }} & \multicolumn{2}{|c|}{ Unstandardized Coefficients } & $\begin{array}{c}\text { Standardized } \\
\text { Coefficients }\end{array}$ & & \\
\hline & & B & Std. Error & Beta & $t$ & Sig. \\
\hline \multirow{2}{*}{1} & (Constant) & 55.788 & 18.337 & & 3.042 & .056 \\
\hline & UMKM & -.007 & .003 & -.812 & -2.413 & .095 \\
\hline
\end{tabular}

a. Dependent Variable: Pengangguran

Berasarkan tabel hasil regresinya diketahui bahwan nilai constant (a) sebesar 55,788, sedangkan nilai UMKM $(\beta /$ kofisien regresi) sebesar $-0,007$ sehingga persamaan regresinya dapat ditulis sebagai berikut:

$$
\begin{gathered}
\mathrm{Y} 1=a+\beta 1 \mathrm{X} \\
\mathrm{Y} 1=55,788-0,007 \mathrm{X}
\end{gathered}
$$

Persamaan tersebut dapat diartikan bahwa:

1) Nilai konstanta sebesar 55,788, dapat diartikan bahwa apabila variabel UMKM (X) sama dengan 0 maka variabel pengangguran (Y1) bernilai sebesar 55,788, dengan kata lain apabila UMKM tidak memberikan pengaruh maka variabel Pengangguran akan naik sebesar 55,788 dalam rentan waktu 2016-2020.

2) Nilai kofisien menunjukkan nilai negative (-), artinya secara parsial hubungan antara variabel UMKM dan variabel tingkat pengangguran menunjukkan hubungan negative dengan Kofisien regresi $X$ sebesar $-0,007$ menyatakan bahwa setiap perkembangan usaha Mikro, Kecil, dan Menengah (UMKM) sebesar 1\% maka tingkat pengangguran akan mengalami penurunan sebesar $0,007 \%$

c. Uji Hipotesis Uji Parsial(Uji-t)

Uji $\mathrm{t}$ dilakukan untuk menunjukkan seberapa jauh pengaruh antara variabel bebas dengan variabel terikat. Adapun kriteria penerimaan dan penolakan hipotesis adalah:

1) Jika $t$ hitung $>t$ tabel Hipotesis diterima

2) Jika thitung $<\mathrm{t}$ tabel Hipotesis ditolak 
Tabel 4. Uji Hipotesis (Uji-t)

\begin{tabular}{|c|c|c|c|c|c|c|}
\hline \multicolumn{7}{|c|}{\begin{tabular}{|rr} 
& Coefficients $^{a}$ \\
\end{tabular}} \\
\hline \multirow{2}{*}{\multicolumn{2}{|c|}{\begin{tabular}{|c|} 
\\
\end{tabular}}} & \multicolumn{2}{|c|}{ Unstandardized Coefficients } & $\begin{array}{l}\text { Standardized } \\
\text { Coefficients }\end{array}$ & \multirow[b]{2}{*}{$\mathrm{t}$} & \multirow[b]{2}{*}{ Sig. } \\
\hline & & $\bar{B}$ & Std. Error & Beta & & \\
\hline 1 & (Constant) & 55.788 & 18.337 & & 3.042 & .05 \\
\hline & UMKM & -.007 & .003 & -.812 & -2.413 & .095 \\
\hline
\end{tabular}

a. Dependent Variable: Pengangguran

Berdasarkan output tabel diatas dapat diketahui niai df (degree of fredoom) sebesar n-k dimana $\mathrm{n}=$ jumlah sampel, dan $\mathrm{k}=\mathrm{jumlah}$ variabel yang diuji, maka 5-2=3 dengan nilai df 3 digunakan untuk mencari t-tabel dengan probabilitas $5 \%$ atau 0,05 dan didapatkan t-tabelnya 2,353 dengan t-hitung sebesar -2.413 dengan kesimpulan bahwa t-hitung -2,413 > 2,353 t-tabel, dengan demikian dapat disimpulkan bahwa Hipotesis diterimah.

\section{d. Uji Korelasi Parsial}

Secara umum uji korelasi bertujuan untuk mengetahui keeratan hubungan antara variabel yang diteliti yakni hubungan antara variabel $\mathrm{X}$ dan $\mathrm{Y}$. korelasi atau hubungan yang terbentuk antar variabel ini dapat bersifat positif atauppun negative. Hal ini dapat dilihat berdasarkan nilai kofisien korelasi dari hasil analisis apakah bernilai (+) atau (-).

Dasar pengambilan keputusan dalam uji korelasi parsial sig. (1-tailed) atau hipotesis satu arah yaitu:

1) Jika nilai sig. (1-tailed) $<$ dari 0,5 maka hipotesis diterimah.

2) Jika nilai sig. (1-tailed) $>$ dari 0,5 maka hipotesis ditolak.

Adapun pedoman derajat hubungan dalam uji korelasi yaitu:

1) Nilai pearson correlation $0,00-0,20=$ tidak terjadi korelasi

2) Nilai pearson correlation $0,21-0,40=$ korelasi lemah

3) Nilai pearson correlation $0,41-0,60=$ korelasi sedang

4) Nilai pearson correlation $0,61-0,80=$ korelasi kuat

5) Nilai pearson correlation $0,81-0,100=$ korelasi Sempurna

Tabel 5. Uji Korelasi Parsial

\begin{tabular}{|l|l|r|r|}
\hline \multicolumn{5}{|c|}{ Correlations } \\
\hline \multirow{3}{*}{ UMKM } & Pearson Correlation & 1 & Pengangguran \\
\cline { 2 - 5 } & Sig. (1-tailed) & & $-.812^{*}$ \\
\cline { 2 - 5 } & $\mathrm{N}$ & 5 & .047 \\
\hline \multirow{3}{*}{ Pengangguran } & Pearson Correlation & $-.812^{*}$ & 5 \\
\cline { 2 - 5 } & Sig. (1-tailed) & .047 & 1 \\
\cline { 2 - 5 } & $\mathrm{N}$ & 5 & 5 \\
\hline
\end{tabular}

*. Correlation is significant at the 0.05 level (1-tailed).

Berdasarkan output tabel 5 Correlation diatas menunjukkan nilai korelasi atau hubungan antara variabel UMKM $(\mathrm{X})$ dan Variabel Pengangguran $(\mathrm{Y})$ berdasarkan nilai signifikansi sebesar 0,047 $<0,05$ maka dapat disimpulkan bahwa hipotesis diterima antara variabel UMKM $(X)$ dan Variabel Pengangguran $(\mathrm{Y})$ terjadi korelasi atau hubungan, sedangkan nilai pearson correlation sebesar $-0,812$ artinya berdasarkan pedoman derajat hubungan maka dapat disimpulkan bahwa korelasi atau hubungan variabel UMKM $(\mathrm{X})$ dan Variabel Pengangguran $(\mathrm{Y})$ berkorelasi sempurna dan tanda (-) mengartikan bahwa antara UMKM dan pengangguran berkorelasi negative yang berarti jika variabel UMKM mengalami kenaikan maka variabel Pengagguran mengalami penurunan.

e. Koefesien Determinasi

Untuk mengetahui seberapa besar pengaruh UMKM (X) terhadap pengangguran (Y), dilakukan perhitungan statistik dengan menggunakan Koefisien Determinasi (KD). 
Tabel 6. Koefisien Determinasi

\begin{tabular}{|l|c|r|r|r|r|}
\hline \multicolumn{7}{|c|}{ Model Summary $^{\mathbf{b}}$} \\
\hline Model & $\mathrm{R}$ & R Square & Adjusted R Square & $\begin{array}{c}\text { Std. Error of the } \\
\text { Estimate }\end{array}$ & Durbin-Watson \\
\hline 1 & $.812^{\mathrm{a}}$ & .660 & .547 & 1.17571 & 3.123 \\
\hline
\end{tabular}

a.Predictors: (Constant), UMKM

b.Dependent Variable: Pengangguran

Output Table 6 menjelaskan bahwa:

1) besarnya nilai korelasi atau hubungan $(R)$ yaitu sebesar 0,812 yang artinya bahwa hubungan antara Usaha Mikro, kecil, dan Menengah dengan pengangguran sebesar 0,812 dengan kata lain hubungannya kuat karena mendekati 1.

2) output kofisien determinasi ( $R$ Square) diperoleh sebesar 0,660, yang artinya bahwa pengaruh Peran variabel bebas (UMKM) dalam mengurangi (pengangguran) variabel terikat sebesar $66 \%$ dan sisanya $34 \%$ di pengaruhi oleh faktor lain diluar penelitian ini.

3) Std. Error of the Estimate artinya ukuran kesalahan prediksi, dengan nilai sebesar 1.17571 artinya kesalahan prediksinya sebesar $11,75 \%$

2. Usaha Mikro,Kecil,dan menengah UMKM (X) dan Kemiskinan (Y2)

a. Uji normalitas

Tabel 7. Uji Normalitas

\begin{tabular}{|l|l|r|}
\hline \multicolumn{2}{|c|}{ One-Sample Kolmogorov-Smirnov Test } & Unstandardized Residual \\
\hline \multicolumn{2}{|c|}{} & 5 \\
\hline N & Mean & .0000000 \\
\cline { 2 - 3 } & Std. Deviation & .13542754 \\
\hline Most Extreme Differences & Absolute & .315 \\
\cline { 2 - 3 } & Positive & .315 \\
\cline { 2 - 3 } & Negative & -.168 \\
\hline Test Statistic & & .315 \\
\hline Asymp. Sig. (2-tailed) & $.116 \mathrm{c}$ \\
\hline
\end{tabular}

a. Test distribution is Normal

b. Calculated from data

c. Lilliefors Significance Correction

$\mathrm{d}$. This is a lower bound of the true significance.

Berdasarkan uji normalitas di ketahui nilai siknifikansi sebesar 0,116 lebih besar dari 0,05 sehingga dapat disimpulkan data yang dilakukan pengujian terdistribusi secara normal.

b. Uji Analisis Regresi Linear Sederhana

Tabel 8. Uji Analisis Regresi

\begin{tabular}{|c|c|c|c|c|c|c|}
\hline \multicolumn{7}{|c|}{ Coefficients ${ }^{a}$} \\
\hline & & \multicolumn{2}{|c|}{ Unstandardized Coefficients } & $\begin{array}{l}\text { Standardized } \\
\text { Coefficients }\end{array}$ & \multirow[b]{2}{*}{$\mathrm{t}$} & \multirow[b]{2}{*}{ Sig. } \\
\hline \multicolumn{2}{|c|}{ Model } & $\mathrm{B}$ & Std. Error & Beta & & \\
\hline \multirow[t]{2}{*}{1} & (Constant) & 22.899 & 2.439 & & 9.389 & .003 \\
\hline & UMKM & -.002 & .000 & -.961 & -6.018 & .009 \\
\hline
\end{tabular}

a. Dependent Variable: Kemiskinan

Berasarkan tabel hasil regresinya diketahui bahwan nilai constant ( $a$ ) sebesar 22,899, sedangkan nilai UMKM ( $\beta$ / kofisien regresi) sebesar $-0,002$ sehingga persamaan regresinya dapat ditulis sebagai berikut:

$$
\begin{gathered}
\mathrm{Y} 2=a+\beta 1 \mathrm{X} \\
\mathrm{Y} 2=22,899-0,002 \mathrm{X}
\end{gathered}
$$

Persamaan tersebut dapat diartikan bahwa:

1) Nilai konstanta sebesar 22,899 , dapat diartikan bahwa apabila variabel UMKM ( $X)$ sama 
dengan 0 maka variabel kemiskinan (Y2) bernilai sebesar 22,899, dengan kata lain apabila UMKM tidak memberikan pengaruh maka kemiskinan akan naik sebesar 22,899, dalam rentan waktu 2016-2020.

2) Nilai kofisien menunjukkan nilai negative (-), artinya secara parsial hubungan antara variabel UMKM dan variabel kemiskinan menunjukkan hubungan negative Nilai kofisien regresi $X$ sebesar -0,002 menyatakan bahwa setiap perkembangan usaha Mikro, Kecil, dan Menengah (UMKM) sebesar 1\% maka Kemiskinan akan mengalami penurunan sebesar 0,002\%.

c. Uji Hipotesis Uji Parsial (Uji-t)

Kriteria penerimaan dan penolakan hipotesis adalah:

1) Jika thitung $>\mathrm{t}$ tabel Hipotesis diterima

2) Jika t hitung $<$ t tabel Hipotesis ditolak

Tabel 9. Uji Hipotesis (Uji-t)

\begin{tabular}{|c|c|c|c|c|c|c|}
\hline \multicolumn{7}{|c|}{ Coefficients ${ }^{a}$} \\
\hline \multirow{2}{*}{\multicolumn{2}{|c|}{ Model }} & \multicolumn{2}{|c|}{ Unstandardized Coefficients } & $\begin{array}{l}\text { Standardized } \\
\text { Coefficients }\end{array}$ & & \\
\hline & & $\mathrm{B}$ & Std. Error & Beta & $\mathrm{T}$ & Sig. \\
\hline 1 & (Constant) & 22.899 & 2.439 & & 9.389 & .003 \\
\hline & UMKM & -.002 & .000 & -.961 & -6.018 & .009 \\
\hline
\end{tabular}

a. Dependent Variable: Kemiskinan

Berdasarkan output tabel diatas dengan dengan niai df (degree of fredoom) sebesar n-k dimana $\mathrm{n}=\mathrm{jumlah}$ sampel, dan $\mathrm{k}=\mathrm{jumlah}$ variabel yang diuji, maka 5-2=3 dengan nilai df 3 digunakan untuk mencari t-tabel dengan probabilitas $5 \%$ atau 0,05 dan didapatkan $\mathrm{t}$-tabelnya 2,353 dengan $\mathrm{t}$-hitung sebesar -6,018 dengan kesimpulan bahwa t-hitung -6,018 $>$ 2,353 t-tabel dengan tingkat signifikansi sebesar 0,009<0,05 demikian dapat disimpulkan bahwa Hipotesis diterimah yang artinya bahwa terdapat hubungan yang signifikan antara variabel UMKM $(\mathrm{X})$ dan Kemiskinan $(\mathrm{Y})$ dan variabel UMKM berkorelasi negative tanda (-) diartikan bahwa korelasi antara Variabel UMKM dan Variabel Kemiskinan berkorelasi negative artinya jika variabel UMKM mengalami kenaikan variabel kemiskinan mengalami penurunan.

\section{d. Koefesien Determinasi}

Tabel 10. Koefesien Determinasi

\begin{tabular}{|l|l|r|r|r|r|}
\hline \multicolumn{7}{|c|}{ Model Summary } \\
\hline Model & \multicolumn{1}{|c|}{ R } & R Square & $\begin{array}{c}\text { Adjusted R } \\
\text { Square }\end{array}$ & $\begin{array}{c}\text { Std. Error of the } \\
\text { Estimate }\end{array}$ & $\begin{array}{c}\text { Durbin- } \\
\text { Watson }\end{array}$ \\
\hline 1 & $.961^{\mathrm{a}}$ & .924 & .898 & .15638 & 2.851 \\
\hline
\end{tabular}

a.Predictors: (Constant), UMKM

b.Dependent Variable: Kemiskinan

Output Table 3 menjelaskan bahwa:

1) besarnya nilai korelasi atau hubungan (R) yaitu sebesar 0,961 yang artinya bahwa hubungan antara Usaha Mikro, kecil, dan Menengah dengan kemiskinan sebesar 0,961 dengan kata lain hubungannya kuat karena mendekati 1.

2) Output koefisien determinasi (R Square) diperoleh sebesar 0,924, yang artinya bahwa pengaruh Peran variabel bebas (UMKM) dalam mengurangi (kemiskinan) variabel terikat sebesar 92,4\% dan sisanya $7,6 \%$ di pengaruhi oleh faktor lain diluar penelitian ini.

3) Std. Error of the Estimate artinya ukuran kesalahan prediksi, dengan nilai sebesar 0,15638 artinya kesalahan prediksinya sebesar $15,63 \%$.

c) Pembahasan

Berdasarkan hasil pengujian, diketahui bahwa Usaha Mikro, Kecil dan Menengah UMKM (X) berpengaruh Negative terhadap Pengangguran,(Y) artinya bahwa setiap UMKM mengalami penambahan tingkat pengangguranpun akan mengalmi penurunan. Selanjutnya dapat dilihat hasil dari t-hitung sebesar -2.413 dengan kesimpulan bahwa t-hitung -2.413 $>$ 2,353 t-tabel maka Hipotesis diterima dan berdasarkan uji korelasi parsial di dapat tingkat sginifikan sebesar 0,047 < dari 0,05 artinya 
terdapat hubungan yang signifikan. Sehingga hal ini menunjukkan bahwa Usaha Mikro, Kecil, dan Menengah berperan secara signifikan dalam Mengurangi tingkat Pengangguran di Kota Palopo. Gunatrin (2017:78) mengatakan bahwa dalam berbagai sektor ekonomi perlu adanya penguatan UMKM dengan cara memberikan peluang usaha bagi UMKM itu sendiri dan pertimbangan keberadaan UMKM agar mampu membangun struktur ekonomi di Indonesia." Dengan harapan adanya UMKM membantu untuk mengatasi masalah ketenagakerjaan dan dapat menambah pendapatan masyarakat, dengan adanya hal tersebut UMKM juga dapat menjadi salah satu solusi jalan untuk mengurangi tingkat pengangguran yang ada.

Untuk mengetahui seberapa besar kontribusi Usaha Mikro, Kecil, dan Menengah dalam mengurangi tingkat pengangguran hasil dari pengujian ini dapat dilihat koefisien determinasinya. Hasil koefisien determinasi dari UMKM adalah 0,660 atau 66\%. Hal ini dapat dikatakan bahwa peran UMKM dalam mengurangi tingkat pengangguran di Kota palopo sebesar $66 \%$, tentunya angka ini sangat besar karena sektor UMKM begitu dominan dalam sebagai ujung tombak dalam mengurangi tingkat pengangguran di Palopo. Hasil ini tentunya angin segar bagi para pelaku UMKM yang ada di Kota Palopo tentunya hal ini juga perlu perhatian serius pemerintah setempat dalam memberikan peluang-peluang bagi munculnya para pelaku-pelaku UMKM baru. Selanjutnya hasil pengujian terhadap Variabel Usaha Mikro Kecil, dan Menengah UMKM (X) dan Kemiskinan (Y) dari hasil pengujiannya didapatkan kesimpulan bahwa UMKM $(X)$ berpengaruh Negative terhadap Kemiskinan (Y) artinya bahwa setiap UMKM mengalami penambahan Kemiskinan akan mengalmi penurunan. Selanjutnya dapat dilihat hasil dari t-hitung $-6,018>2,353 \mathrm{t}$-tabel dan nilai signifikansi sebesar 0,009< 0,05 dengan demikian dapat disimpulkan bahwa Hipotesis diterimah dan terjadi hubungan yang signifikan antara UMKM dan Kemiskinan Sehingga hal ini menunjukkan bahwa Usaha Mikro, Kecil, dan Menengah UMKM berperan secara signifikan dalam Mengurangi kemiskinan di Kota Palopo.

Untuk mengetahui seberapa besar kontribusi Usaha Mikro, Kecil, dan Menengah dalam mengurangi kemiskinan dapat dilihat koefisien determinasi. Hasil koefisien determinasi dari UMKM adalah 0,924 atau $92,4 \%$. Hal ini dapat dikatakan bahwa peran UMKM dalam mengurangi kemiskinan di Kota palopo sebesar 92,4\% angka ini sangat besar karena sektor UMKM begitu dominan dalam pengentasan kemiskinan di Palopo. Tujuan akhir program kebijakan pembangunan di Indonesia pada saat ini tentunya adalah untuk peningkatan kesejahteraan masyarakat sesuai alinea ke 4 UUD 1945 menciptakan kesejahtraan umum, terkait kesejahtraan masyarakat tentunya dapat dilihat atas pemenuhan kebutuhan dasar masyarakat, kesejahtraan tidak akan tercapai jika masyarakat masih hidup dalam garis kemiskinan, dimana kemiskinan yang merupakan masalah yang ada setiap daerah termasuk di Kota Palopo, dan juga merupakan masalah klasik yang dari tahun ke tahun dijadikan sebagai objek politik untuk menarik simpati masyarakat. Sebagaimana telah dijelaskan mengenai peran serta UMKM dalam mengurangi tingkat kemiskinan. Peran UMKM dinilai sangat strategis. jika pemberantasan kemiskinan adalah tujuan utama setiap kebijakan pembangunan, maka upaya penyediaan lapangan kerja serta peningkatan penghasilan orang miskin adalah tujuan terpenting, dan peran usaha Mikro, Kecil, Dan Menengah UMKM dapat diyakini sebagai pendukung utama perekonomian rakyat. Tumbuhnya UMKM sebagai juga sumber kesempatan kerja dan meningkatkan pendapatan dan banyak menyerap tenaga kerja, dengan demikian UMKM memiliki peran strategis dalam mengentaskan kemiskinan dan penggangguran. Dibalik begitu pentingnnya peranan UMKM juga terdapat beberapa kendala yang dihadapi oleh para pelaku UMKM kendala yang paling banyak dikeluhkan selama ini yaitu akses pemodalan, peran serta pemerintah juga sangat dibutuhkan guna menghidupkan antusiasme masyarakat dalam berwirahusaha.

Palopo Sebagai kota yang sangat strategis karena terletak diantara 4 kabupaten didukung dengan pesatnya pembangunan-pembangunan serta dukungan-dukungan pemerintah setempat terhadap perkembangan Usaha Mikro, Kecil dan Menengah salah satu contohnya dengan begitu mudahnya pemberian izin tempat usaha baru bagi para pelaku usaha sektor UMKM dan akses bantuan modal dengan adanya KUR untuk menopang dari segi pendanaan, dengan kemudahan tersebut UMKM sebagai ujung tombak dalam meningkatkan kesejahtraan masyarakat Kota Palopo diharapkan terus tumbuh dan memberikan kontribusi nyata terhadap kemajuan Kota Palopo ke arah yang positif.

Berdasarkan hasil yang diperoleh dalam penelitian ini dapat disimpulkan bahwa: Variabel usaha Mikro, Kecil dan Menengah UMKM berpengaruh negative dalam mengurangi tingkat pengangguran. Dengan kata lain, hubungan usaha Mikro, Kecil, dan Menengah UMKM dan tingkat pengangguran memiliki hubungan berlawanan. yang artinya semakin berkembangnya Usaha mikro, 
kecil, dan menengah tingkat pengangguran akan mengalami penurunan dengan begitu UMKM berperan dalam menurunkan tingkat pengangguran di Kota Palopo. Sedangkan Variabel usaha Mikro, Kecil dan Menengah UMKM juga berpengaruh negative dalam mengurangi kemiskinan terhadap tingkat kemiskinan. Dengan kata lain, hubungan usaha Mikro, Kecil dan, Menengah UMKM dan Kemiskinan memiliki hubungan berlawanan. yang artinya semakin berkembangnya Usaha mikro, kecil, dan menengah maka kemiskinanpun akan mengalami penurunan dengan begitu UMKM berperan dalam menurunkan kemiskinan di Kota Palopo.

\section{Saran}

Berdasarkan kesimpulan diatas dari hasil analisis dari berbagai data dan informasi maka penulis menyarankan:

1. Untuk pemerintah kota palopo terus melakukan upaya agar usaha Mikro, Kecil, dan Menengah UMKM semakin berkembang agar upaya mengurangi tingkat pengangguran dan kemiskinan melalui pemberdayaan UMKM bisa dimaksimal.

2. Untuk masyarakat agar mencoba berwirausaha dengan ikut sebagai pelaku UMKM selain sebagai alternatif pekerjaan juga dapat menghindarkan dari garis kemiskinan.

3. Untuk Dinas UMKM atau pihak terkait diharapkan memberikan dukungan penuh dalam penggembangan UMKM yang ada di Kota Palopo.

\section{DAFTAR PUSTAKA}

Aida, N. (2021). Work Experience, Obedience Pressure and Task Complexity on Audit Judgment. Golden Ratio of Auditing Research, 1(2), 1 - 8. https://doi.org/10.52970/grar.v1i2.51

Agustina, T., Gerhana, W., \& , S. (2020). The Effect of Locus of Control, Learning, and Adversity Quotient towards Micro Business Success (Study on Entrepreneurship under Foster Group of the Banjarmasin Regional Government). Journal of Wetlands Environmental Management. https://doi.org/10.20527/jwem.v8i1.215

Ahmad, F., Aditya Halim Perdana Kusuma, P., Zainuddin, M., Gunawan Bata, I., \& Kasnaeny, K. (2020). Reconceptualization of Business Model for Marketing Nowadays: Theory and Implications. Journal of Asian Finance, Economics and Business, 7(7), 279-291.

Akob, M., Arianty, R., \& Putra, A. H. P. K. (2020). The mediating role of distribution Kahns engagement: An empirical evidence of salesforce in Indonesia. Journal of Asian Finance, Economics and Business, 7(2), 249-260. https://doi.org/10.13106/jafeb.2020.vol7.no2.249

Alam, N., Aida, N., \& Mukhtar, A. (2021). Effect of Financial Performance on Stock-Prices in Food and Beverages Firm . Golden Ratio of Finance Management, 1(2), 61 - 74. https:/ / doi.org/10.52970/grfm.v1i2.63

Andiny, P., \& Nurjannah, N. (2018). Analisis Pemberdayaan Usaha Mikro Kecil dan Menengah (UMKM) sebagai upaya Penanggulangan Kemiskinan di Kota Langsa. Jurnal Serambi Ekonomi Dan Bisnis, 5(1), 31-37.

Arfah, A., Olilingo, F. Z., Syaifuddin, S., Dahliah, D., Nurmiati, N., \& Putra, A. H. P. K. (2020). Economics During Global Recession: Sharia-Economics as a Post COVID-19 Agenda. The Journal of Asian Finance, Economics and Business, 7(11), 1077-1085.

Asmin, E. A., Ali, M. ., Nohong, M. ., \& Mardiana, R. . (2021). The Effect of Financial Self-Efficacy and Financial Knowledge on Financial Management Behavior . Golden Ratio of Finance Management, 1(2), 75 - 86. https://doi.org/10.52970/grfm.v1i1.59

BAPPENAS. (2016). Indeks Keparahan Kemiskinan Menurut Kabupaten / Kota , 2015 - 2016. 2015-2016.

Birčiaková, N., Stávková, J., \& Antošová, V. (2014). The Impact of Economic Development in the Czech Republic on the Income Inequality between Groups of Households. Procedia Economics and Finance, 12(March), 57-65. https:// doi.org/10.1016/s2212-5671(14)00320-7

Ceric. (2017). Electronic HRM in the Smart Era. Electronic HRM in the Smart Era. https://doi.org/10.1108/9781787143159

Dahliah, D., Kurniawan, A., \& Putra, A. H. P. K. (2020). Analysis and Strategy of Economic Development Policy for SMEs in Indonesia. The Journal of Asian Finance, Economics and Business, 7(5), 103-110.

Gaffar, S., \& Uleng Akal, A. T. (2021). Quantitative Analysis of Leverage Ratio on Earning-Per-Share of Property and Real Estate Sectors in Indonesia. Golden Ratio of Finance Management, 1(2), 101 - 113. https://doi.org/10.52970/grfm.v1i2.58

Ghoshray, A., Ordóñez, J., \& Sala, H. (2016). Euro, crisis and unemployment: Youth patterns, youth policies? Economic Modelling, 58, 442-453. https://doi.org/10.1016/j.econmod.2016.05.017

Ghozali, I. (2011). Ekonometrika: teori, konsep dan aplikasi dengan SPSS 17. Badan Penerbit Universitas Diponegoro. Semarang Indonesia.

Haerani, S., Sumardi, Hakim, W., Hartini, \& Putra, A. H. P. K. (2020). Structural Model of Developing Human Resources Performance: Empirical Study of Indonesia States Owned Enterprises. The Journal of Asian 
Finance, Economics and Business, 7(3), 211-221.

Halvarsson, D., Korpi, M., \& Wennberg, K. (2018). Entrepreneurship and income inequality. Journal of Economic Behavior and Organization, 145, 275-293. https://doi.org/10.1016/j.jebo.2017.11.003

Haming, M., Murdifin, I., Zulfikar Syaiful, A., \& Aditya, H. P. K. P. (2019). The Application of SERVQUAL Distribution In Measuring Customer Satisfaction of Retails Company. Journal of Distribution Science, 17(2), 25. https://doi.org/10.15722/jds.17.02.201902.25

Hayati, N., \& Rukhviyanti, N. (2016). Leadership Capability for Market Orientation and Learning Orientation and Its Impact on the Institution Performance and Competitiveness: A Case of STIE Indonesia. Procedia - Social and Behavioral Sciences, 219, 291-298. https://doi.org/10.1016/j.sbspro.2016.04.033

Hermanto, M. (2016). Analisis Laba Usaha Dengan Menggunakan Metode Economic Value Added (EVA) Pada Koperasi Karyawan Tirta Mahakam di Tenggarong. Jurnal Ekonomi \& Manajemen Indonesia, 8(1).

Ilyas, G. B., Rahmi, S., Tamsah, H., Munir, A. R., \& Putra, A. H. P. K. (2020). Reflective Model of Brand Awareness on Repurchase Intention and Customer Satisfaction. The Journal of Asian Finance, Economics and Business, 7(9), 427-438.

Indahingwati, A., Launtu, A., Tamsah, H., Firman, A., Putra, A. H. P. K., \& Aswari, A. (2019). How Digital Technology Driven Millennial Consumer Behaviour in Indonesia. Journal of Distribution Science, 17(8), 25-34.

Islam, S. M. D. U., Bodrud-Doza, M., Khan, R. M., Haque, M. A., \& Mamun, M. A. (2020). Exploring COVID-19 stress and its factors in Bangladesh: A perception-based study. Heliyon, 6(7), 1-10. https://doi.org/10.1016/j.heliyon.2020.e04399

Jenkins, W. (2009). Sustainability theory. In Berkshire Encyclopedia of Sustainability.

JS Saragih. (2017). Krimininalitas Dituntut Untuk Mendapat Perhatian. Repository.Uma.Ac.Id/Bitstream/123456789/1307/4/128400195_file4.Pdf. http://repository.uma.ac.id/bitstream/123456789/1307/4/128400195_file4.pdf

Kamakura, W. A., \& Mazzon, J. A. (2015). Measuring the Impact of a Conditional Cash Transfer Program on Consumption Behavior with Propensity Scoring. Customer Needs and Solutions, 2(4), 302-316. https://doi.org/10.1007/s40547-015-0037-0

Keshvari, R. S. (2012). The impact of E-CRM on customers attitude and its association with generating competitive advantages in Iranian financial B2B context. International Business Research, 5(4), 34.

Khurshid, H., \& Snell, R. S. (2021). Examining mechanisms for creating shared value by Asian firms. Journal of Business Research, 129(February), 122-133. https://doi.org/10.1016/j.jbusres.2021.02.030

Laurens, S., \& Putra, A. H. P. K. (2020). Poverty Alleviation Efforts through MDG's and Economic Resources in Indonesia. The Journal of Asian Finance, Economics and Business, 7(9), 755-767.

Lestari, S. D., Leon, F. M., Widyastuti, S., Brabo, N. A., \& Putra, A. H. P. K. (2020). Antecedents and Consequences of Innovation and Business Strategy on Performance and Competitive Advantage of SMEs. The Journal of Asian Finance, Economics and Business, 7(6), 365-378.

Lorenzo, J. R. F., Rubio, M. T. M., \& Garcés, S. A. (2018). The competitive advantage in business, capabilities and strategy. What general performance factors are found in the Spanish wine industry? Wine Economics and Policy, 7(2), 94-108. https://doi.org/10.1016/j.wep.2018.04.001

Maksimov, V., Wang, S. L., \& Luo, Y. (2017). Reducing poverty in the least developed countries: The role of small and medium enterprises. Journal of World Business, 52(2), 244-257. https://doi.org/10.1016/j.jwb.2016.12.007

Mappamiring, M., Akob, M., \& Putra, A. H. P. K. (2020). What Millennial Workers Want? Turnover or Intention to Stay in Company. The Journal of Asian Finance, Economics and Business, 7(5), 237-248.

Masripatin, N. (2007). Land Use, Land Use Change and Forestry in the Context of A / R. Kyoto Mechanism and the Conservation of Tropical Forest Ecosystem. Proceedings of the International Symposium/Workshop, Waseda University, Tokyo, Japan, 29-30 January 2004.

Muslim, M. R. (2014). Pengangguran terbuka dan determinannya. Jurnal Ekonomi \& Studi Pembangunan, 15(2), 171-181.

Mustika, C. (2012). Pajak Penghasilan Di Indonesia (Peraturan,Perhitungan dan Upaya Peningkatan Potensi Penerimaan) dan Kaitannya Dengan Invetsasi di Indonesia. Mankeu, Vol. 1, No, 227-238.

Nurhilalia, Rahman Kadir, A., Mahlia, M., Jusni, \& Aditya, H. P. K. P. (2019). Determinant of market orientation on SME performance: RBV and SCP perspective. In Journal of Distribution Science (Vol. 17, Issue 9, pp. 3545). https://doi.org/10.15722/jds.17.09.201909.35

Olilingo, F. Z., \& Putra, A. H. P. K. (2020). How Indonesia Economics Works: Correlation Analysis of Macroeconomics in 2010-2019. Journal Asian Finance Economic and Business, 7(8), 117-130.

Putra, Aditya Halim, Aswari, A., Arifin, M. Y., \& Rina, R. (2018). Quantitative Series: Factors Analysis Effects of Government Regulation Number 46 the Year 2013 For SME's by Justice, Convenience, and Simplicity of Tax Aspects. Substantive Justice International Journal of Law, 1(2), 65-81.

Putra, Adnan Husada. (2016). Peran UMKM dalam Pembangunan dan Kesejahteraan Masyarakat Kabupaten Blora. Jurnal Analisa Sosiologi, 5(2).

Rachmawati, M. (2020). Kontribusi Sektor Umkm Pada Upaya Pengentasan Kemiskinan Di Indonesia. Jurnal 
Ekonomi, Sosial \& Humaniora, 1(07), 1-13.

Ramlawati, Putra, A. H. P. K., Yasni, Basalamah, J., \& Mappatompo, A. (2019, July). Why Millenials Eat Out From Home? BT - 1st International Conference on Life, Innovation, Change and Knowledge (ICLICK 2018). https://www.atlantis-press.com/article/125913306

Rombe, Y. (2021). The Analysis of Financial Statements Performance: Case Studies PT. Bank Negara Indonesia (Persero) . Golden Ratio of Finance Management, 1(2), 87 - 100. https://doi.org/10.52970/grfm.v1i2.53

Sett, R. K. (2018). Market orientation - firm performance link in a dynamic environment: looking inside the black box. AMS Review, 8(3-4), 163-179. https:/ / doi.org/10.1007/s13162-017-0099-2

Simanjuntak, M., \& Putra, A. H. P. K. (2021). Theoretical Implications of Theory Planned Behavior on Purchasing Decisions: A Bibliometric Review. Golden Ratio of Mapping Idea and Literature Format, 1(2), 1-7.

Strat, V. A., Davidescu(Alexandru), A., \& Paul(Vass), A. M. (2015). FDI and The Unemployment - A Causality Analysis for the Latest EU Members. Procedia Economics and Finance, 23(October 2014), 635-643. https://doi.org/10.1016/S2212-5671(15)00448-7

Sugiyono. (2014). Metode Penelitian Pendidikan Pendekatan Kuantitatif, Kualitatif dan R\&D. In Metode Penelitian Pendidikan Pendekatan Kuantitatif, Kualitatif Dan RED. https:/ / doi.org/10.1007/s13398-014-0173-7.2

Sukirno, S. (2004). Makroekonomi teori pengantar. Jakarta: PT Raja Grafindo Persada.

Švárová, M., \& Vrchota, J. (2014). Influence of Competitive Advantage on Formulation Business Strategy. Procedia Economics and Finance, 12(March), 687-694. https:// doi.org/10.1016/S2212-5671(14)00394-3

Tahir, M., Khan, I., \& Shah, A. M. (2015). Foreign Remittances, Foreign Direct Investment, Foreign Imports and Economic Growth in Pakistan: A Time Series Analysis. Arab Economic and Business Journal, 10(2), 82-89. https://doi.org/10.1016/j.aebj.2015.06.001

Tangngisalu, J., Mappamiring, M., Andayani, W., Putra, M. Y., \& Kusuma, A. H. P. (2020). CSR and Firm Reputation from Employee Perspective. Journal of Asian Finance, Economics and Business, 7(10), 171-182.

Tohmo, T. (2018). The economic impact of tourism in Central Finland: a regional input-output study. Tourism Review, 73(4), 521-547. https://doi.org/10.1108/TR-04-2017-0080

Vuong, B. N., Tung, D. D., Hoa, N. D., Chau, N. T. N., \& Tushar, H. (2020). An Empirical Assessment of Organizational Commitment and Job Performance: Vietnam Small and Medium-Sized Enterprises. The Journal of Asian Finance, Economics and Business, 7(6), 277-286.

Wang, W., Phillips, P. C. B., \& Su, L. (2019). The heterogeneous effects of the minimum wage on employment across states. Economics Letters, 174, 179-185. https:/ / doi.org/10.1016/j.econlet.2018.11.002

Wibawa, R. P., \& Anggitaria, N. R. (2020). Kontribusi Usaha Mikro Kecil Menengah (Umkm) Dalam Mengurangi Tingkat Pengangguran. Jurnal Ilmiah Pendidikan Ekonomi, 5(1). 